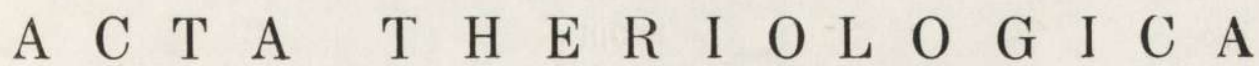 \\ VOL. XII, 23: $349-360$ \\ BIAŁOWIEŻA \\ 30.XII.1967
}

Janusz GILL

\section{The Physiological Properties of the European Bison}

\section{Bisoniana XIX}

[With 1 Table \& 3 Figs.]

\begin{abstract}
Research so far carried out on the physiological properties of the European bison has developed in 4 directions: 1 . General data on the physiology of reproduction has been examined, paying particular attention to the changes taking place in the occurrence of the sexual cycle over the course of a year in the case of European bison in reserves and living in freedom. 2. A small number of studies on questions of nutrition and digestion, or more strictly speaking - the digestibility of food and rate of it passage through the alimentary tract. 3. Dead animals used for investigation of the size of the alimentary tract, the weight of its contents and number of Infusoria in the stomach divisions. 4. Acute experiments carried out on animals under deep anaesthesia referred to such problems as: regulation of blood pressure and respiration, electrocardiographic examination of the heart, neurohormonal influence, number of glycoprotein fractions in the blood serum. In the majority of cases the animals used had been eliminated from the herd for various reasons and often were abnormal In order to obtain informations on the physiological properties of the European bison it is however essential to carry out further investigations on physiologically normal animals.
\end{abstract}

\section{INTRODUCTION}

The consequences of the European bison's nature as a ruminant are not infrequently overlooked, particularly from the aspect of adaption. For what is the ruminant from the point of view of evolutionary physiology? In order to answer this question we must go back in thought to the times when there was fierce competition for food rich in nutrient components and at the same time digestible, that is, accessible to the animal's enzymes, by means of which it could obtain the whole of the store of energy and essential building material accumulated in the food.

There is deep-seated conflict at this point of contact between the plant and animals worlds. Plants are the only source of matter and energy contained in chemical compounds available to animals. The chief and most accessible energy material for the animals are the molecules of glucose bounded in the greater carbohydrate particles. The plant synthetises the glucose molecules in the form of two variants of glucosides $-a$ and $\beta$, depending on which $\mathrm{OH}$ group of the reacting carbon of the glucose molecule the next particle combines with - the right or the left. This slight variation in position of one compound has important biological 
consequences. Only starch and some disaccharides are variant $a$ glucosides, while the majority of plant carbohydrates are variant $\beta$ glucosides. The animals formed enzymes catalysing only the variant $\alpha$ glucoside compound (M o i r, 1965).

The incapacity for producing of enzymes attacking variant compounds of an enormous amount of plant material during the course of physiological adaptation led to many animal organisms dying out as the result of lack of food. It was a question primarily of lack of cellulase enzyme, the presence of which would not nnly have permitted of utilizing the rich energy material of the supporting tissues of plants, but also would have opened the walls of plant cells and by doing so have rendered the access to compounds forming the interior of the cells. The whole of these compounds can be utilized already by animal enzymes. Over the long process of evolution the animals have not attained the capacity for synthetizing cellulase in their tissues, despite the production of so enormous number of other enzymes.

In addition as evolution progressed, the need for highly synthetised and more complex molecular configurations, such as are vitamine continually increased. They became essential to the functioning of the majority of the enzymes produced. At the same time, however, evolution led to the loss by part of the more biologically advanced organisms, of the capacity for synthesis of prosthetic groups ( $\mathrm{M}$ o i $\mathrm{r}, l$.c.).

In this circumstances a certain group of animals began to tend towards intimate symbiosis with bacteria, both those possessing the capacity for vitamin synthesis and those which produce cellulase and as a result are capable of hydrolysing $\beta$ variant glucoside compounds. These are, however, anaerobic organisms. Conditions had therefore to be created in the alimentary tract in which they would have not cnly abundance of substrate bur also peace to work and anaerobic conditions. The pouchs of the stomach were therefore formed, among which was a capacious rumen, in which there would have been suitable living conditions for bacteria and utilization of the results of their action if the system regulating the movement of the alimentary tract had not been inherited from the animals' forebears. This regulation consisted in automatic contractions of the muscles of the tract, which were however strictly subject to the control of the cerebral cortex and hence susceptible to all emotional influences. Peace and slow mixing of contents is essential to the work of bacteria, since only under such conditions is it possible to utilize the products of their action. It was therefore necessary to adjust the neuro-hormonal regulating mechanisms in such a way as to ensure that as far as the rumen was concerned the inhibiting processes predominated over the excitatory processes. It is far more advantageous to arrest the movements of the rumen even for a several minutes than - in the opposite case - violent to movement of $100 \mathrm{~kg}$ of food mass from one place to another within few seconds.

Under these circumstances the centre regulating the movements of the pouches of the stomach was moved from the medulla oblongata to the higher layers of the cerebrum and rendered independent of the centres connected with the co-ordination of skeletal muscle contractions and emotional influences. With such a work of alimentary tract the ruminants were enabled to make full use of the advantages of symbiosis with micro-organisms. The metabolism and energy conversion were shifted from glucose, as a medium, to the volatile fatty acids produced by bacteria. This in turn made further independence from the environment possible, by protecting the endogenic storages of water and nitrogen, which led to the circulation of water and nitrogen within each organism. This fact neabled ruminants to settle down in the most varied parts of the Earth, from equatorial deserts to the Polar regions. 
The translocation of the nerve centres essential to life to new regions of the brain brought about far-reaching changes in nervo-hormonal regulation. The most distinct expression of this is the lack of sleep in the form found in the case of animals with simple-stomachs, and the group of characters which are colloquially defined as wildness. This is perhaps not only the effect of translocation of the centres referred to, the localisation of which has remained undiscovered up to the present, but also of the relatively weak development of the cerebral cortex. It is however an undeniable fact that over the period of about 7.000 years a man has only succeeded in domesticating a small number of species of ruminants. The great majority, however, do not submit to the influence of a man in the sence of changes in mental and metabolic reaction.

Even in domesticated a very strong defensive reaction has been retained to such changes in environment and surroundings as noise, change of food or feeder or milkmen of the animals. Is it therefore possible to imagine that anyone could succeed in domesticating during his life a ruminant which has remained wild up to the present, such as red deer, fallow deer, antelope or gazelle? Most certainly not and this fact must be accepted.

The European bison is the most typical ruminant in which the process of domestication, in the sence of physiological changes, has most probably not even begun. The fact that it has now lived for several generations near to and under the care of a man has had a somewhat strange effect on its psychical traits, as far as behaviour is concerned. Namely when it is set free it does not escape from man like the red or fallow deer, but even quite the contrary - in certain situations it seeks contact with man, e. g. approaching farm enclosures in the winter, or reacting to the sound of a mechanical saw (eating the top shoots). On this account the present-day European bison cannot therefore be treated as a game animal.

On the other hand all the characteristics of wildness have been retained, as regards direct contact with man, which make it impossible to speak as yet of domestication. It is only in the reproduction processes that man's care has exerted a fairly significant, but apparently transitory effect on the physiology of the European bison. The abundance of food rich in protein, vitamins and especially oestrogenic compounds and alkaloids sensitizing the animals to the action of light have resulted that in animals kept in enclosed reserves and particularly in zoological gardens deprived of the natural treestand beeing more lighted, the reproduction season proper to the ruminants, begun to be to a certain degree labile in the European bison. The proof of this was the fact that bison calves were born in all the months of the year. Figure 1 taken from the study by $\mathrm{Jaczewski}(1958)$ shows that this process has slowly intensified in enclosures. This was not however due to permanent changes, as is shown by the births of calves in the Białowieża Primaeval Forest reserves over the last 12 years (a fairly stable environment). When, however, the animals moved from the reserves into the Forest to food which was mostly natural, within a few years the physiology of the reproductive system began returning to its normal rhythm. An illustration of this is formed by the births of European bison calves over the last 7 years (Krasiński \& Raczyński, 1967 - see p. 411, Fig. 1). The data given by these authors show that the calving period rapidly narrowed 
to, in principle, the five summer months. It would seem that this is a good example of the fact that under more natural environment conditions the metabolism of bison rapidly frees itself of the influences imposed upon it by man.

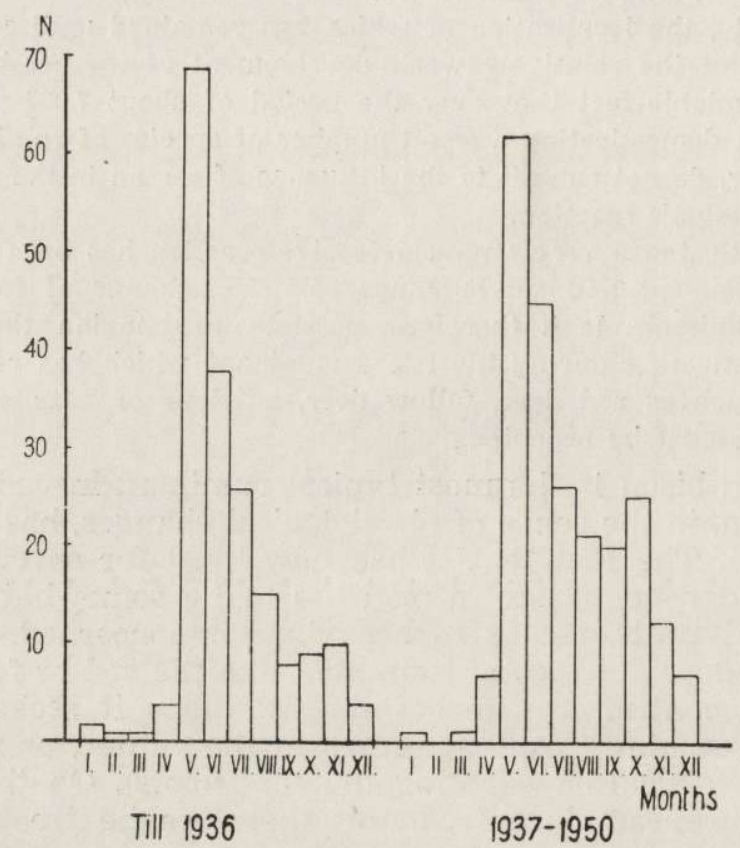

Fig. 1. Births in European bison in the various months: up to 1936 and between 1937 and 1950 in reserves (acc. to J a c z e w s ki, 1958, changed).

A further example of the resistance of the bison's nervous system is provided by comparison of the susceptibility to anaesthesia of this species and that of other representatives of the subtype Bovina (Gill, 1962) These relations are presented in Fig. 2, which shows that doses almost 5 times as great are required to produce complete anaesthesia in the European bison than are required by domestic cattle, and twice as great as for ruminants which are in fact domesticated in their native countries (buffalo, yak) but whose metabolism has not yet been adjusted to the same extent to the production of milk or meat as the European breeds of cattle.

\section{TRENDS IN RESEARCH}

The correctness of the reasonings presented above is also confirmed by literature on the physiology of the European bison, and should be decisive in plans for future research. In literature on the European bison there can be no results, of such great importance to all physiological investigations, as the number of pulsations depending on sex and age, the lines of aeration of the lungs, skin temperature under different conditions, 
recording of movements of the alimentary tract, quality of sperm, movements of the embryo, composition of the beestings and milk of female European bison in different states of lactation, or even basic data on the physiology of the new-born calf.

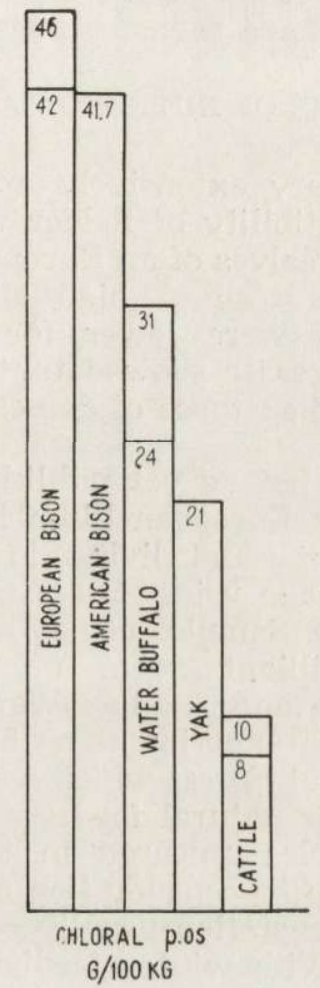

Fig. 2. The doses of chloralhydrate (grams per $100 \mathrm{~kg}$ of body weight) necessary to produce deep surgical anaesthesia in some ruminants.

It is necessary to resigue from such information for at least a long period of time, but even now it is possible to accumulate information and carry out planned physiological investigation in four basic directions: 1. General data on the physiology of reproduction, chiefly on the basis of observations in reserves and among free-living animals, 2. Questions of nutrition and digestion - experiments and observations. 3. Utilization of dead or killed animals. 4. Wide-scale acute experiments under deep anaesthesia.

In the present situation the first, second and third directions are capable of being put into effect to different extents, depending on current and future possibilities. Physiological investigations in acute experiments have their own established methods and ways of interpretation. In addition they make it possible to investigate the basic regulating mechanisms in a state in which the influence of the habitat and any other additional stimuli, apart from those applied by the investigator, are 
completely eliminated. In the case of animals which have retained their wild nature this is the only method of obtaining information on the functioning of their organism.

In beginning a short review of the results obtained from research on the physiology of the European bison I shall omit the first direction, as questions of reproduction have been discussed in a separate paper.

\section{PROBLEMS OF NUTRITION AND DIGESTION}

This direction is not very extensively represented. Szaniawski (1960) compared the digestibility of fodder with different protein ratios in relation to 6-month old calves of an European bison and domestic cow. $\mathrm{He}$ found that both in the case of high and low protein content the coefficients of digestibility were lower for European bison than for domestic calf. Weight increases showed that the requirements of European bison are not lower than those of domestic calves, as has sometimes been suggested.

My own investigations, not as yet published ( $\mathrm{Gill}$, in prep.) on the rate of passage of food in European bison living in zoological gardens, in the reserve at Białowieża and living in freedom in the Białowieża Primaeval Forest, were made using B a l c h's (1950) method appropriately modified (G ill, 1960). Samples of hay and power feed were stained with basic fuchsine or brilliant green. A total of 14 experiments were carried out in the reserve and in the Warsaw and Gdańsk Zoos on 5 European bison, and one experiment on 5 free-living European bison in the Białowieża Primaeval Forest which were supplied with hay in the winter to supplement their natural food.

The first undigest particles appeared in the faeces of the European bison from 13-22 hours after consumption of the food, most often from $17-18$ hours after. Peak excretion usually occurred on the 4th day, and ended after 8-17 days. With winter feeding the food remained in the alimentary tract longer than in spring and summer, when the European bison could feed on green fodder. This is in accordance with the general physiology of the alimentary tract.

In faeces collected for estimation of rate of food passage examination was also made for the degree of crumbling of the particles, contents of air dry matter and possible occurrence of swelling bodies.

\section{INVESTIGATION USING EUROPEAN BISON DEAD FROIM NATURAL CAUSES OR KILLED}

This direction is of apparently less importance to physiology than the other three, since it only permits on investigation of material fixed by one or another method. In the case of rare animals, however, this type of material is also of considerable importance. The interest shown in the alimentary tract of the European bison must take first place here.

The number of Infusoria was ascertained in the contents of rumen and reticulum in 17 individuals of European bison (partially published Gill, 1954). In animals which had retained their appetite up to the end of their lives the number of Infusoria in $1 \mathrm{~mm}^{3}$ of rumen contents varied 
from 685 to 2030 , and in the reticulum from 680 to 2877 . In the case of animals given antibiotics in their food the number of Infusoria was: 6336 in the rumen and 5574 per $1 \mathrm{~mm}^{3}$ in the reticulum, whereas in European bison which for various reasons had not consumed food for a time before their death, the number of Infusoria was far smaller, being 96-897 in the rumen and 129-834 in the reticulum. Among the two families of Infusoria in the rumen Ophyryoscolecidae formed from 67.19 to $99.12 \%$, and Isotrichidae - $0.28-32.81 \%$. The latter analysis was made of stomach contents of 4 European bison of the "Pu « line.

The dry mass, water, crude fibre and silica contents were determined in the digesta of the whole alimentary tract of 5 European bison (Gill \& Rydzyński, in prep.). The percentage of water and crude fibre is given in fig. 3 . The respective indices have not as yet been calculated and I cannot therefore give the capacity of the different parts of the alimentary tract in the European bison for disintegrating crude fibre.

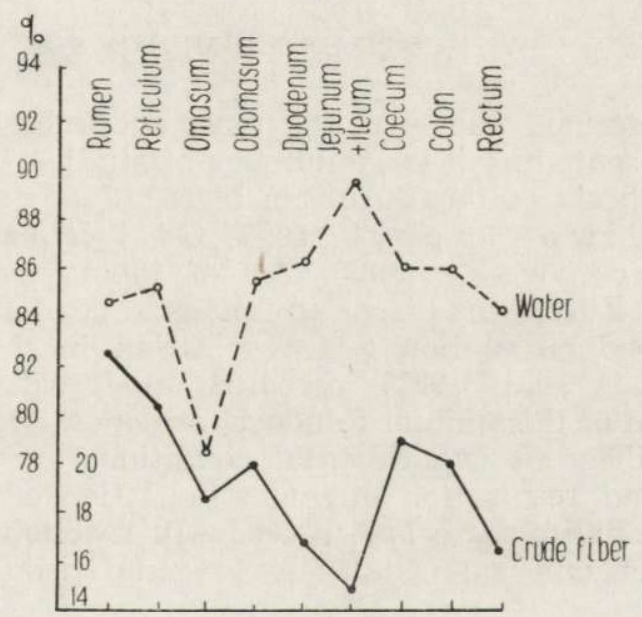

Fig. 3. The contents of water and crude fiber (per cent) in air dry digesta of European bison.

The capacity of the alimentary tract (by $\mathrm{K}$ was nicki's method, 1952), weight of digesta and weight of the walls of the tract emptied of contents (Gi11, 1965) was determined for 6 bull bison. In the case of 4 animals the so-called maximum postmortem capacity was determined, varying from 268-276 litres in 3 adult animals, and 106.3 litres in the one-year old bull calf (Pud). In the case of 2 animals capacity was measured after previously fixing the cadavers by pumping fixative into the vascular system (Pilarski et al., 1967). In this case the total volume of the alimentary tract of a 10 -month old calf was 36 litres, and of an adult bull - 87 litres. In this last case the animal was kept without water for a few days before giving it anaesthetics to drink. It must be assumed that its alimentary tract did not function completely normally during dehydration, and hence its capacity was so small.

The weight of the food contents was determined in 3 adult bulls and 
a 13-month old bull calf. In two of the bulls (Pluvius II and Plater), which continued eating up to the end of their lives, the contents of the alimentary tract were respectively 64 and $78 \mathrm{~kg}$, the third of them (Plato) had been dehydrated before administering chloralhydrate (G ill \& J ac z e w s k i, 1961). The contents of the tract in this animal weight $28.5 \mathrm{~kg}$. The contents of the tract of the 13-month old calf (killed in the herd) weighed $29.8 \mathrm{~kg}$. The weight of the walls of the whole alimentary tract was from $25.7-33.1 \mathrm{~kg}$ in the three adult bulls and $10.6 \mathrm{~kg}$ in the calf. From the weight aspect the whole alimentary tract formed from 12$13 \%$ and only in the case of the dehydrated Plato - $7 \%$.

In comparison with other species of the subtype Bovina (Gill, 1965) the European bison has the maximum capacity and maximum weight of walls of the alimentary tract, which most certainly enables it to utilize large amounts of ligneous, indigestible plant food - primarily thanks to bacteria and to its own enzymes.

\section{ACUTE EXPERIMENTS}

The direction defined above as the most accessible for experimental research, is represented by a large number of studies. These are the first studies on anaesthesia in the European bison: J a c z e w ski \& S w i eżyńs ki, 1955; P i w ow a rczyk, 1967; Gill \& Jaczewski, 1961; Gill, 1962; Jaczewski, 1963. All of them emphasise the great resistance of the European bison to anaesthetics. The first study on regulation of blood circulation and respiration in the European bison (Gill \& Jaczewski, 1961) revealed the great sensitivity of the circulatory system of this animal to neurohormones. Systolic and diastolic pressure under different experimental conditions and the behaviour of blood pressure and respiration during stimulation of the trunk of the vago-sympathetic nerve were also given. All reactions are in general typical, and differ only quantitatively in comparison with other large ruminants.

The glycoprotein fractions were identified in the blood serum of 3 European bison and divided into hexose and sialic acids (D ż u ły ńs k a et al., 1964). Among the proteins of the blood serum of the European bison the greatest was the albumin fraction (over $50 \%$ ), and among the glycoproteins - the $\alpha_{2}$-globulin fraction ( $50 \%$ of the whole). This picture was almost the same as in the case of the buffalo and very similar to that in the case of cattle. The ratio of sialic acids: $\mathrm{N}$ - acetyloneuramino to $\mathrm{N}$ - glycoliloneuramino was 1.0 in the European bison and was almost the same as in the buffalo and domestic cattle, and completely different than in other species of mammals. The ratio of hexoses to sialic acids in the blood serum albumin was 1.8 for the European bison and 2.1 for the buffalo.

The next problem is the electrocardiographic examination of the heart of European bison during deep anaesthesia, administration of neurohormones and bleeding. In this sphere one study has already been published ( $\mathrm{Nagórski} \&$ Grodzki, 1966) and a second is being prepared (Gill \& Grodzki, in prep.). In the latter it was found that during anaesthesia normal sinus rhythm occurs in the European bison (Plamiec). 
After injecting $2 \mathrm{mg}$ of adrenalin blood pressure enhanced from 94 to $110 \mathrm{~mm} \mathrm{Hg}$, and pulse from 90 to 200 beats per minute. The electrocardiogram exhibited symptoms of myocardiac oxygen insufficiency manifested by a reversed, deep and peaked deflection T. These changes disappeared after 130 seconds.

After a similar dose of noradrenalin the increase in pressure from 76 reached $125 \mathrm{~mm} \mathrm{Hg}$, and pulse from 98 to 230 per minute. ECG also exhibited symptoms of oxygen insufficiency. Impulses originating from the lower centres of the stimulus conducting system appeared. These changes were not evened out until 3 minutes later.

A dose of $2 \mathrm{mg}$ of acetylocholin caused a drop in pressure from 94 to $25 \mathrm{~mm} \mathrm{Hg}$. ECG exhibited very intensive retardation of the function of the sinoatrial node. The ventricles were however stimulated with frequency of 11 impulses per minute, and the atria -22 per minute, that is, every second impulse was blocked by the atrioventricular node. This was an atrioventricular block of II degree. It was not until 54 impulses per minute were reached that the full atrioventricular groups appeared. Pulse fell from 84 to 11 per minute, after 30 seconds increased to 75 , and after $1^{1 / 2}$ minutes to 92 per minute.

Table 1.

Results of recording of arterial blood pressure, heart rate, frequency of respiration and bleeding volume in 7 European bisons.

\begin{tabular}{|l|c|c|c|c|c|c|c|}
\hline $\begin{array}{c}\text { Name } \\
\text { of European } \\
\text { bison }\end{array}$ & $\begin{array}{c}\text { Age, } \\
\text { years }\end{array}$ & $\begin{array}{c}\text { Body wt. } \\
\text { kg. }\end{array}$ & $\begin{array}{c}\text { Blood } \\
\text { pressure } \\
\text { mm Hg }\end{array}$ & $\begin{array}{c}\text { Heart } \\
\text { rate } \\
\text { per min. }\end{array}$ & $\begin{array}{c}\text { Respira- } \\
\text { tion } \\
\text { per min. }\end{array}$ & Bleeding volume & liters \\
\hline & & $\begin{array}{c}\text { Per cent } \\
\text { of body } \\
\text { weight }\end{array}$ \\
\hline Plato & 17 & 750 & 180 & 56 & 8 & 17.0 & 2.27 \\
Pluszcz & 10 & 620 & 126 & - & 11 & - & - \\
Pomian & 6 week & 57 & 192 & 116 & 30 & 0.19 & 0.33 \\
Puzota & 2 & 217 & 126 & 154 & 13 & 4.3 & 2.00 \\
Puck & 4 & - & 85 & 114 & 20 & 5.1 & - \\
Putar & - & - & 76 & 136 & 16 & 12.2 & - \\
Plamiec & 14 & - & 120 & 85 & 8 & 19.0 & - \\
\hline
\end{tabular}

Defaecation took place 4 minutes after administration of acetylocholin. This took place in fact in almost all cases of injection of acetylocholin.

Further examinations refer to experiments on regulation of blood circulation and respiration not only in old males but also in a 2-year old cow and 6-week old calf (G ill, in prep.). Histomin and serotin were also introduced into the experiments, and finally examination of the response of the cardiovascular system to neurohormones administered during loading of the organism with lactic acid. In this last case the results obtained in relation to 2 European bisons seem to indicate that the European bison is an animal adapted to intensive and lengthy muscular effort.

The results obtained by studies made up to the present on regulation of blood circulation and respiration under deep anaesthesia (Gill, in prep.) recorded at the beginning of each experiment are set out in Table 1. It can be seen from it that individual differences are very great 
and that by post experiment bleeding, directly from the carotid artery a relatively very small amount of blood was generally obtained in comparison with other species bled in the same way. It is not known whether this is due to the sparing supply of blood during anaesthesia, or whether it is evidence of the small amount of blood in the European bison altogether. It is difficult to agree with this last view, especially in view of my own investigations of the effect of lactic acid on the circulatory system.

\section{CONCLUSION}

Many facts have been presented in this paper which undoubtedly provide information on the physiological properties of the animals examined. But can these be taken as fully representing the physiology of the European bison? The majority of the animals examined were either old or diseased animals, or had some defect due to illnesses or mechanical injures (e.g. fracture of the pelvis - Puzota, eye injury Plato, ossified joints of the limbs - Pluvius II, completely blind - Pomian). It arises from this that Poland has as yet very few European bison, and far too few to alocate specimens normal in all respects for physiological investigations. Only such European bison however would make it possible to obtain representative results, which can be discussed without reservation, as they are data typical of the species Bison bonasus.

\section{REFERENCES}

1. B a l ch C. C, 1950: Factors affecting the utilization of food by dairy cows. 1 . The rate of passage through the digestive tract. Brit. J. Nutr., 4: $361-388$, London.

2. Dżułyńska J., Krajewska K. \& Gill J., 1964: Serum glycoproteins in some species of non-domesticated mammals. Acta biochim. polon.; 11: 121128. Warszawa.

3. Gasparski J., 1962: Studies of the antigenic factors of the blood of aurochs (Bison bonasus). Ann. N. Y. Acad. Sc., 97, 1: 285-295. New York.

4. Gil1 J., 1954: Badania wymoczków w treści pokarmowej żubrów (Bison bonasus L.). Acta physiol. pol., 5: 530-533. Warszawa.

5. Gill J., 1960: Die Durchgangszeiten der Nahrung durch den Verdauungskanal des Elches. Trans. 4th Congr. Intern. Union Game Biologists: 155- 164. Arnhem.

6. Gill J., 1962: Narkoza u niektórych gatunków zwierząt nieudomowionych. Biul. II Zj. PTNW: 19-20. Wrocław.

7. Gill J., 1965: Pojemność i ciężar przewodu pokarmowego niektórych gatunków podplemienia Bovina. Mat. VIII Zj. PTZool.: 42-43. Olsztyn.

8. Gill J. \& Grodzki K., M. S.: Wplyw adrenaliny, noradrenaliny i acetylocholiny na ciśnienie krwi i obraz elektrokardiograficzny serca żubra Bison bonasus (L.) w doświadczeniu ostrym.

9. Gill J. \& J a czewski Z., 1961: Regulation of blood pressure in the European bison, Bison bonasus (L.). Acta physiol. pol., 12: 859-867. Warszawa.

10. Jaczewski Z., 1958: Reproduction of the European Bison. Bison bonasus (L.), in reserves. Acta theriol., 1, 9: 333-376. Warszawa. 
11. J a czewski Z., 1963: Działanie na żubra (Bison bonasus (L.) chlorku tubokuraryny podawanego przy pomocy wyrzucanej strzykawki automatycznej. Streszcz. Refer. i Komunik. IX Zj. P.T.Fizjol.: 108. Toruń.

12. Jaczewski Z. \& Swierzyński K., 1955: Anaesthesis in the European Bison (Bison bonasus L.) by chloralhydrate (chloralum hydratum). Zool. pol. 6: 80 -87. Warszawa.

13. Moir R. J., 1965: The comparative physiology of ruminant-like animals. In [R. W. Dougherty et al. "Physiology of digestion in the ruminant«: 1-14. Butterwords, London].

14. Krasiński Z. \& Raczyński J., 1967: The reproduction biology of European bison living in reserves and in freedom. Acte theriol., 12, 29: 407-444.

15. K waśnicki A. W., 1951: Fizjologija piščevarenija u svinej. Selhozgiz. Moskva.

16. Nagórski F. \& Grodzki K., 1966: Elektrokardiogram umierającego serca u żubrów (Bison bonasus) w warunkach eksperymentu. Biul. III $\mathrm{Zj}$. PTNW: 140-141. Lublin.

17. Pilarski W., Serwatka S., Swieżyński K. \& Węgrzyn M., 1967: New attempts at fixing anatomical material of large mammals. Acta theriol., 12, 31: $453-458$.

18. Piwowarczyk S.. 1967: Narcosis induced in European bison by means of chloral hydrate and ethyl alcohol. Acta theriol., 12, 32: 467-470.

19. Szaniawski A., 1960: Comparison digestibility of feedingstuffs with different protein ratios for calves of domestic cattle and of bison, Bison bonasus (L.). Acta theriol., 3, 13: 318-319.

Received, March 26, 1967.

Warsaw Agricultural University,

Dept. of Animal Physiology,

Warszawa, Grochowska 272.

Janusz GILL

\section{FIZJOLOGICZNE WŁAŚCIWOŚCI ŻUBRA}

\section{Streszczenie}

Omówiono fizjologiczne przyczyny i trudności w udomawianiu przeżuwaczy oraz różnice $\mathrm{w}$ zachowaniu się ich $\mathrm{w}$ porównaniu $\mathrm{z}$ innymi grupami zwierząt. Następnie podkreślono szybkie przestawianie się fizjologii rozrodu żubra $\mathrm{z}$ typu zbliżonego do przeżuwaczy udomowionych w hodowli zamkniętej (Ryc. 1) do bardziej charakteryzującej dzikie przeżuwaczy - zaledwie w kilka lat po wyjściu z rezerwatów na wolność.

Dużą oporność żubrów na wodnik chloralu, w porównaniu z innymi przeżuwaczami (Ryc. 2) przedstawiono jako cechę organizmu nie przystosowanego do sprawnego reagowania na stress. 
Z kolei omówiono wykonane badania, zarówno opublikowane jak i nie, nad strawnością paszy u cielęcia żubra, szybkością transportu treści pokarmowej i stopniem jej rozdrobnienia, liczbą wymoczków w treści żwacza i czepca. Podano pojemność przewodu pokarmowego, ciężar jego ścian i zawartości, ilość w niej wody i surowego włókna (Ryc. 3).

Wreszcie podano prace opisujące przebieg narkozy u żubra i badania nad regulacją ciśnienia krwi i oddechu (Tabela 1), nad ilością frakcji glikoproteinowych surowicy krwi oraz elektrokardiograficzne badania serca żubrów w czasie snu narkotycznego, wpływów neurohormonalnych i podczas wykrwawiania.

W zakończeniu podkreślono fakt, iż do badań fizjologicznych przekazuje się bardzo małą liczbę żubrów, co musi świadczyć o zbyt niskim stanie pogłowia żubrów w Polsce w stosunku do potrzeb nauki. 